\title{
HUBUNGAN KARAKTERISTIK FISIK DAN KIMIA BEBERAPA JENIS BUAH MANGGA (Mangifera indica L) TERHADAP PENERIMAAN KONSUMEN
}

\section{Oksilia $^{1}$}

\author{
Email Author: oksilia@gmail.com
}

\begin{abstract}
ABSTRAK
Penelitian ini bertujuan untuk menganalisis hubungan antara karakteristik fisik dan kimia beberapa jenis mangga (Mangifera indica $\mathrm{L}$ ) terhadap penerimaan konsumen. Penelitian ini menggunakan metode Rancangan Acak Lapangan dengan satu faktor yaitu tiga jenis mangga, Kuweni, Gedong dan Harum Manis serta analisa sensoris yang meliputi atribut warna dan rasa. Hasil penelitian menunjukkan terdapat hubungan antara karakteristik fisik dan kimia beberapa jenis mangga terhadap skor kesukaan panelis terhadap warna dan rasa.
\end{abstract}

Kata kunci: mangga, sensoris, kimia

\begin{abstract}
This research aimed to analyze the relation between physic and chemical characteristics at three kinds of mango (Mangifera indica L) to consumer preference by using sensoric test. This research method using field randomized design with one factor and sensoric analysis which color attribute and flavour attribute. The results showed that there was the relation between physic and chemical characteristics of three kinds of mango (Mangifera indica L) to hedonic score of panelis, flavour dan color.
\end{abstract}

Keyword: mango, sensoric, chemical

\section{PENDAHULUAN}

Karakterisik fisik, kimia serta atribut mutu sensoris buah-buahan merupakan faktor penting dalam menentukan kepuasan konsumen dan mempengaruhi tingkat konsumsi. Kualitas buah-buahan dapat ditentukan melalui karakteristik fisik misalnya warna dan karakteristik kimia yang meliputi total gula, $\mathrm{pH}$ dan lain-lain.

Rasa, aroma dan warna merupakan pertimbangan utama konsumen dalam memilih buah, salah satunya buah mangga. Mangga (Mangifera indica L) termasuk salah satu buah tropis yang bersifat musiman.
Mangga termasuk buah yang termasuk dalam suku Anacardiaceae. Banyak kultivar yang telah dibudidayakan, antara lain Gedong, Harum Manis, dan Kuweni.

Mutu hasil hortikultura segar didefinisikan sebagai kombinasi dari karakteristik dan sifat-sifat yang memberikan nilai komoditas sebagai bahan makanan. Secara umum mutu akhir buah yang dihasilkan dipengaruhi oleh faktor prapanen (mutu benih/bibit, lingkungan tempat tumbuh, agroklimat dan teknik budidaya tanaman) serta faktor pascapanen (umur petik, pemanenan,dan penanganan hasil

\footnotetext{
${ }^{1}$ Fakultas Pertanian Universitas Taman Siswa Palembang
} 
panen). Menurut Kader (2002), konsumen mangga menilai perfoma mutu mangga tergantung pada parameter mutu eksternal atau penampilan visual (bebas memar, bebas getah, bebas cedera, berat, warna, dan bentuk) dan pada parameter mutu internal (warna daging, kerusakan, tingkat keasaman, dan derajat kemanisan). Komponen mutu eksternal merupakan penilaian pertama yang dapat memberi gambaran tingkat mutu suatu komoditas karena dapat terlihat langsung. Dalam pemasaran, mutu visual merupakan faktor yang sangat penting, karena konsumen akan lebih dulu menilai hal yang terlihat langsung. Komponen yang berhubungan dengan mutu eksternal terdiri dari bentuk, ukuran, warna, kesegaran, kebersihan, kerusakan fisik, dan kerusakan mikrobiologis.

Faktor-faktor internal yang meliputi warna, rasa, dan aroma dapat tercermin dari tingkat penerimaan konsumen melalui uji sensoris dan erat kaitannya dengan karakteristik fisik dan kimia buah manga.

Penelitian ini bertujuan untuk menganalisis hubungan antara karakteristik fisik dan kimia mangga (Mangifera indica L.) terhadap penerimaan konsumen melalui uji sensoris.

\section{METODE PENELITIAN}

\section{Alat dan Bahan}

Alat-alat yang digunakan dalam praktikum mandiri adalah texture analizer merk Brookfield, hand refractometer, $\mathrm{pH}$ meter (Lutron $\mathrm{YK}$ 2001, Jerman), color reader (Minolta CR 1 Jepang), timbangan analitik Ohaus.
Bahan yang digunakan dalam pelaksanaan penelitian ini adalah tiga jenis mangga yaitu Gedong, Harum Manis dan Kuweni yang diperoleh dari supermarket di kota Palembang.

\section{Rancangan Penelitian}

Penelitian dilakukan dengan menggunakan Rancangan Acak Lapangan dengan satu perlakuan yaitu jenis mangga dan ulangan sebanyak 2 kali. Data yang diperoleh melalui sensoris dihitung secara statistik yang digunakan adalah non parametrik model Friedman-Conover yang telah diperbaiki oleh Davenport pada tahun 1980 dalam Sudjono (1985), khusus untuk uji organoleptic.

\section{Prosedur Kerja}

Penelitian dimulai dengan persiapan sampel. Masing-masing sampel mangga di kupas kemudian dicuci bersih lalu dipotong-potong dadu dengan ukuran $5 \mathrm{~cm} \times 5 \mathrm{~cm} \times 5 \mathrm{~cm}$. Masingmasing sampel yang terdiri dari mangga Gedong, Kuweni dan Harum manis disajikan kepada 30 panelis. Panelis diminta untuk memberikan penilaian terhadap rasa, warna dan aroma masingmasing manga.

\section{Pengamatan dan Pengumpulan Data}

Pengamatan dan pengumpulan data untuk karakteristik fisik dan kimia dilakukan berdasarkan parameter $\mathrm{pH}$ (Hutching, 1999), warna (AOAC, 1995) dan total gula. Sedangkan data hasil uji sensoris dianalisa menggunakan uji Friedmann-Conover (Soekarto dan Sudjono, 1985). 


\section{HASIL DAN PEMBAHASAN}

\section{A. Karakteristik Fisik dan Kimia}

Karakteristik fisik dan kimia yang diamati dalam penelitian ini meliputi total gula, $\mathrm{pH}$ dan warna.

\section{Total Gula}

Gula merupakan komponen yang penting untuk mendapatkan flavour buah yang menyenangkan melalui perimbangan gula dan asam. Hasil dari percobaan yang dilakukan, gula total mangga berkisar antara $16,20 \%$ brix sampai $18,15 \%$ brix. Rerata total gula tertinggi diperoleh oleh buah mangga jenis harum manis sebesar $18,15 \%$ brix, sedangkan rerata total gula terendah diperoleh buah mangga jenis kuweni. Rata-rata gula total mangga untuk semua jenis mangga dapat dilihat pada Gambar 1.

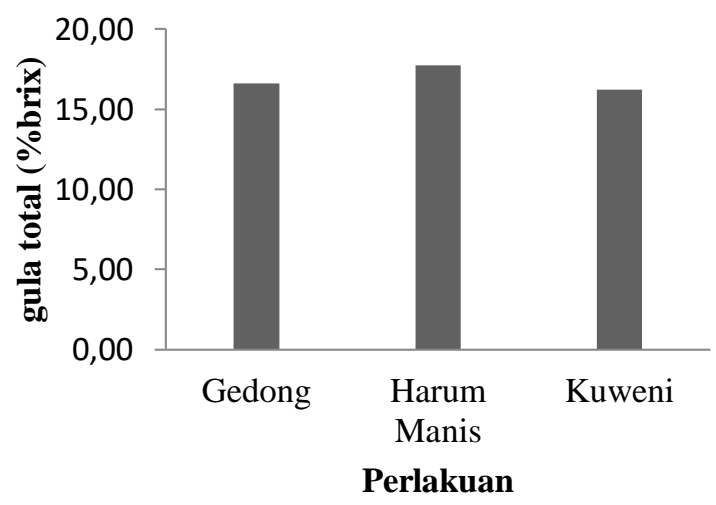

Gambar 1. Rata-rata total gula manga

\section{2. $\mathbf{p H}$}

Kandungan asam pada buah sangat beragam, tergantung jenisnya. Umumnya, kandungan asam pada buah akan menurun selama pematangan dan memiliki waktu yang berbeda beda saat proses tersebut berlangsung. Hasil percobaan menunjukkan $\mathrm{pH}$ mangga berkisar antara 5,04 sampai 6,43. Rata- rata $\mathrm{pH}$ tertinggi terdapat pada jenis mangga kuweni sedangan $\mathrm{pH}$ terendah terdapat jenis mangga harum manis. Rata-rata nilai $\mathrm{pH}$ untuk semua jenis mangga dapat dilihat pada Gambar 2.

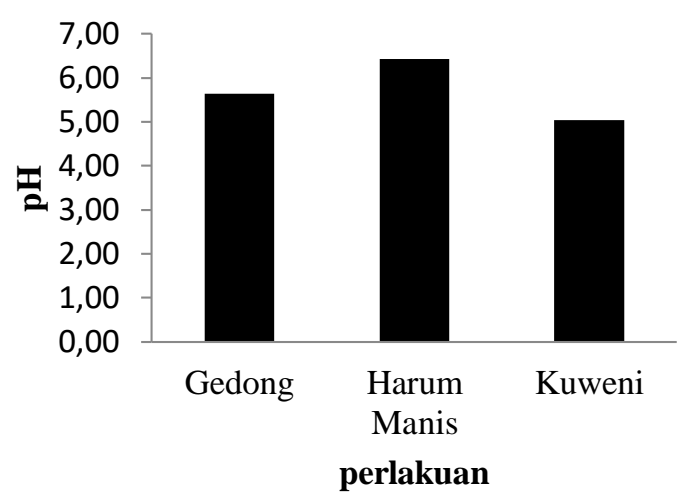

Gambar 2. Rata-rata nilai pH manga

\section{Warna}

Warna merupakan salah-satu atribut yang dapat mempengaruhi mutu suatu produk. Warna pada bahan pangan mempunyai peranan penting dalam menentukan penerimaan dan member petunjuk mengenai perubahan yang terjadi dalam bahan makanan. Warna pad bahan makanan dapat berasal dari beberapa sumber, seperti pigmen yang ada pada bahan pangan nabati atau hewani. Menurut Desrosier (1988), warna bahan pangan dipengaruhi oleh kondisi permukaan bahan pangan dan kemampuannya menyerap, memantulkan, meneruskan dan menyebarkan sinar yang Nampak. Pengukuran intensitas warna mangga dengan menggunakan color reader. Komponen yang diamati meliputi lightness (L), nilai a dan nilai $\mathrm{b}$.

Lightness menunjukkan tingkat kecerahan atau terang gelapnya suatu warna. Menurut Hutching (1999), lightness dinotasikan dengan L. Lightness mempunyai nilai 0 (hitam) 
sampai dengan 100 (putih). Nilai a merupakan warna kromatik campuran merah dan hijau dengan kisaran (-80)100. Kisaran 0-100 termasuk +a yang menunjukkan warna merah dan kisaran (-80)-0 termasuk -a yang menunjukkan warna hijau. Sedangkan nilai $b$ merupakan warna kromatik campuran kuning dan biru dengan kisaran (-80)-70. Kisaran $\quad 0-70$ termasuk $+b$ yang menunjukkan warna kuning dan kisaran (-80)-0 termasuk -b yang menunjukkan warna biru (Hutching, 1999). Hasil pengukuran warna pada masing-masing jenis buah mangga dapat dilihat pada Gambar 3.

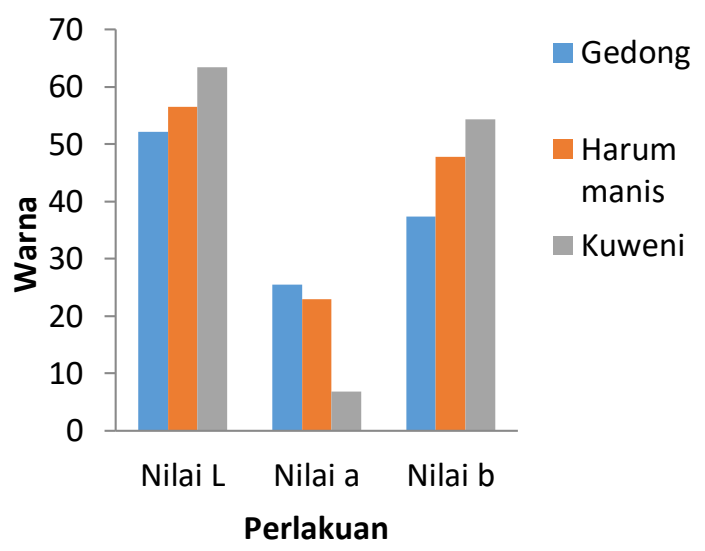

Gambar 3. Rata-rata nilai L, a dan b manga

Berdasarkan hasil pengamatan nilai rerata lightness mangga berkisar antara $52,12 \%$ sampai $63,15 \%$. Nilai a berkisar antara 6,85 sampai 25,5, sedangkan nilai b berkisar antara 37,35 sampai 54,3.

Hasil analisis keragaman menunjukkan perbedaan jenis mangga berpengaruh nyata terhadap warna (nilai a dan nilai b), gula total dan $\mathrm{pH}$ mangga. Uji BNJ pengaruh perbedaan jenis mangga terhadap warna, gula total dan pH dapat dilihat pada Tabel 1.
Tabel 1.Uji BNJ pengaruh perbedaan jenis mangga terhadap warna, total gula dan $\mathrm{pH}$

\begin{tabular}{|c|c|c|c|c|}
\hline \multirow{2}{*}{$\begin{array}{l}\text { Jenis } \\
\text { mangga }\end{array}$} & \multicolumn{2}{|l|}{ Warna } & \multirow{2}{*}{$\begin{array}{l}\text { Gula } \\
\text { total }\end{array}$} & \multirow[t]{2}{*}{$\mathrm{pH}$} \\
\hline & $\begin{array}{l}\text { Nilai } \\
\text { a }\end{array}$ & $\begin{array}{l}\text { Nilai } \\
\text { b }\end{array}$ & & \\
\hline $\mathrm{Ge}$ & 2550 & 73 & & $J, 0$ \\
\hline $\begin{array}{l}\text { Harum } \\
\text { Manis }\end{array}$ & $b^{\mathrm{b}}$ & 47 & 18 & 6,4 \\
\hline Kuweni & $6,85^{\mathrm{a}}$ & $54,30^{\mathrm{b}}$ & $16,20^{\mathrm{a}}$ & 5,0 \\
\hline
\end{tabular}

Keterangan: Angka-angka yang diikuti oleh huruf yang sama pada kolom yang sama menunjukkan perbedaan yang tidak nyata

Hasil uji BNJ taraf 5\% menunjukkan bahwa warna mangga kuweni berbeda nyata dengan mangga jenis Gedong dan Harum manis. Mangga harum manis memiliki total gula yang berbeda nyata dengan jenis mangga Gedong dan Kuweni, sedangkan $\mathrm{pH}$ mangga jenis Kuweni berbeda nyata dengan jenis mangga Gedong dan Harum Manis.

\section{B. Uji Sensoris}

Sifat sensoris merupakan hasil reaksi fisiopsikologis berupa tanggapan atau kesan pribadi seorang panelis sehingga hasil uji sangat bersifat subjektif (Soekarto, 1985). Dalam percobaan ini, atribut mutu sensoris yang diuji terdiri atas uji hedonik untuk rasa dan warna. Uji kesukaan (hedonic test) dilakukan untuk melihat penerimaan panelis terhadap kesukaan tiga jenis mangga, yaitu gedong, harum manis dan kuweni yang disajikan dengan memberikan penilaian berkisar antara sangat tidak suka (1) sampai sangat suka (5).

\section{Warna}

Warna merupakan hasil respon yang diterima mata dari rangsangan fisik berupa cahaya (Soekarto dan Hubeis, 
2000). Hasil uji kesukaan terhadap warna tiga jenis mangga berkisar antara 2,82 (biasa) sampai 4,59 (suka). Tingkat kesukaan tertinggi dengan skor 4,59 untuk jenis mangga Gedong dan tingkat kesukaan terendah untuk jenis mangga kuweni. Rerata skor warna ketiga jenis mangga disajikan pada Gambar 4.

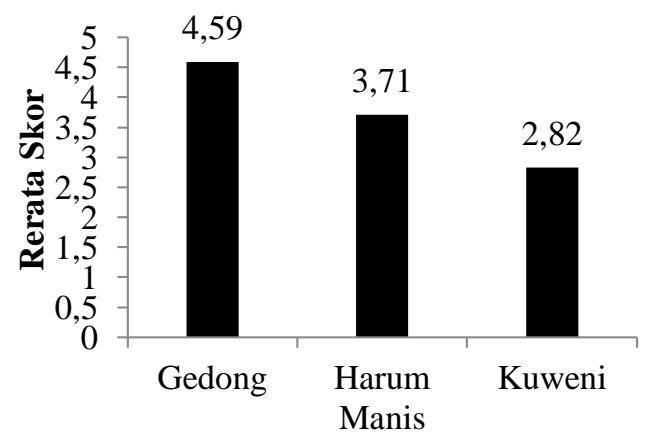

Jenis mangga

Gambar 7. Rata-rata skor hedonik terhadap warna manga

Uji hedonik warna buah mangga dilakukan karena warna pada buah sangat mempengaruhi penampilan dan daya tarik buah tersebut. Menurut Winarno (1997), makanan yang berkualitas baik tidak akan dipilih bila memiliki warna yang tidak sedap dipandang atau memberi kesan telah menyimpang dari warna seharusnya.

Tabel 2. Uji lanjut Friedman-Conover terhadap warna manga

\begin{tabular}{llcc}
\hline Jenis Mangga & $\begin{array}{l}\text { Jumlah } \\
\text { pangkat }\end{array}$ & $\mathrm{X}=5,47$ \\
\hline Kuweni & \multicolumn{2}{c}{$20 \mathrm{a}$} \\
$\begin{array}{l}\text { Harum Manis } \\
\text { Gedong }\end{array}$ & \multicolumn{2}{c}{$\mathrm{a}, 5$} & $\mathrm{~b}$ \\
Keterangan: Angka-angka yang diikuti oleh \\
huruf yang sama pada kolom yang sama \\
menunjukkan perbedaan yang tidak nyata
\end{tabular}

Hasil uji lanjut Friedman-
Conover terhadap warna mangga menunjukkan bahwa warna ketiga jenis mangga berbeda nyata

\section{Rasa}

Rasa merupakan campuran dari tanggapan cicip, bau dan trigeminal. Penilaian panelis terhadap rasa diartikan sebagai daya terima terhadap citarasa atau flavour yang dihasilkan oleh sebuah produk.

Skor penilaian panelis terhadap rasa mangga berkisar antara 3,06 (biasa) sampai 4,35 (suka). Skor tertinggi untuk jenis mangga harum manis dan skor terendah untuk jenis mangga kuweni. Rata-rata skor penilaian panelis terhadap rasa mangga dapat dilihat pada Gambar 4.

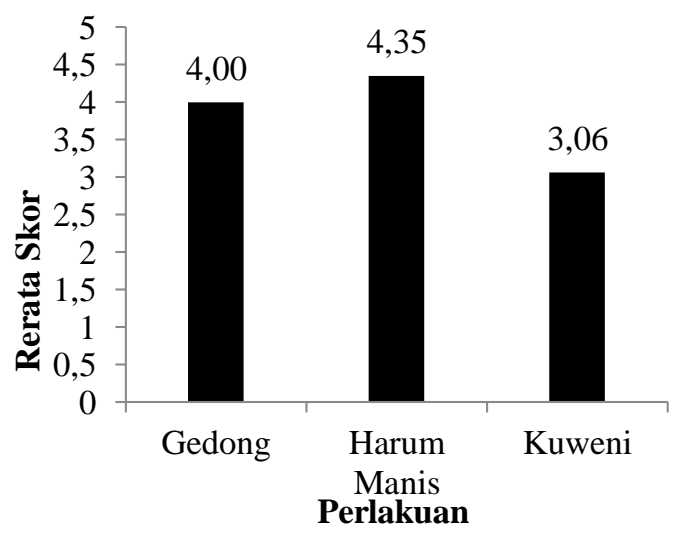

Gambar 8. Rata-rata skor hedonik terhadap rasa manga

\section{Hubungan antara Karakteristik Fisik, Kimia dan Sensoris}

Karakterisik fisik, kimia serta atribut mutu sensoris buah-buahan merupakan faktor penting dalam menentukan kepuasan konsumen dan mempengaruhi tingkat konsumsi. Perbandingan karakteristik fisik, kimia dan sensoris mangga dapat dilihat pada Gambar 5. 


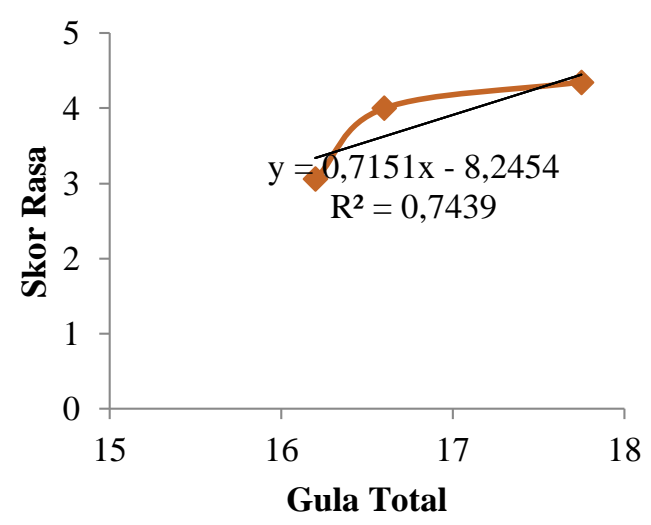

Gambar 5a. Hubungan Gula Total terhadap skor rasa

Buah-buah tropis umumnya memiliki rasa manis dan asam. Rasa yang terdapat pada buah-buah tersebut dapat mempengaruhi penerimaan konsumen. Karbohidrat oleh tanaman disimpan di dalam buah untuk persediaan energi, saat proses pematangan buah kandungan karbohidrat (pati) dan gula selalu berubah. Perubahan gula di dalam buahbuahan menyangkut kandungan sukrosa, glukosa, dan fruktosa. Gambar 9a menunjukkan bahwa peningkatan gula total pada mangga menyebabkan skor panelis semakin meningkat. Hubungan antara gula total dan skor rasa panelis ditunjukkan dengan persamaan berikut:

Skor Rasa $=0,715$ (gula total) $-8,245$ dengan $r^{2}=0.743$.

Komponen rasa yang juga erat kaitannya dengan skor panelis adalah asam. Kandungan asam pada buah sangat beragam, tergantung jenisnya. Umumnya, kandungan asam pada buah akan menurun selama pematangan dan memiliki waktu yang berbeda-beda saat proses tersebut berlangsung. Kandungan asam pada buah dapat ditunjukkan dengan mengukur $\mathrm{pH}$ buah tersebut. Hubungan antara $\mathrm{pH}$ dan skor kesukaan panelis terhadap rasa dapat dilihat pada Gambar 5b.

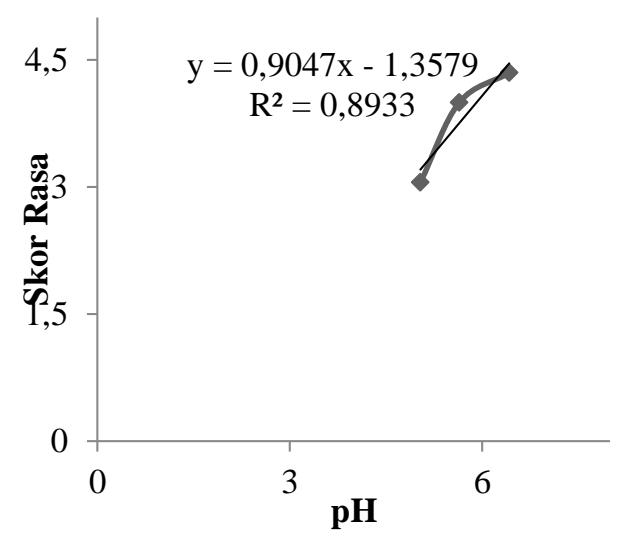

Gambar 5b. Hubungan $\mathrm{pH}$ terhadap skor rasa manga

Buah-buahan yang masih muda banyak mengandung asam-asam organik dimana selama proses pematangan, kandungan asam organik ini akan menurun. Asam-asam organik yang terkandung pada buah dapat mempengaruhi rasa dan aroma. Asamasam organik yang biasa terdapat pada buah-buahan adalah asam askorbat, asetat, malat, sitrat, dan sebagainya (Muchtadi dan Sugiono, 1992). Gambar 9b menunjukkan bahwa peningkatan nilai $\mathrm{pH}$ mengakibatkan skor kesukaan panelis terhadap rasa mangga semakin tinggi. Nilai $\mathrm{pH}$ yang tinggi menunjukkan keasaman buah menurun dan sebaliknya. Hubungan antara nilai pH dan skor kesukaan panelis terhadap rasa mangga dapat ditunjukkan dengan persamaan berikut:

Skor rasa $=0,904(\mathrm{pH})-1.357$ dengan $\mathrm{R}^{2}=0,893$

Atribut mutu sensoris yang berkaitan dengan penerimaan konsumen lainnya adalah warna. Uji hedonik warna buah mangga dilakukan karena warna pada buah sangat mempengaruhi 
penampilan dan daya tarik buah tersebut. Menurut Winarno (1997), makanan yang berkualitas baik tidak akan dipilih bila memiliki warna yang tidak sedap dipandang atau memberi kesan telah menyimpang dari warna seharusnya.
Hubungan pengukuran warna dengan Color Reader (nilai L, a dan b) terhadap skor kesukaan panelis terhadap rasa dapat dilihat pada Gambar 5c.

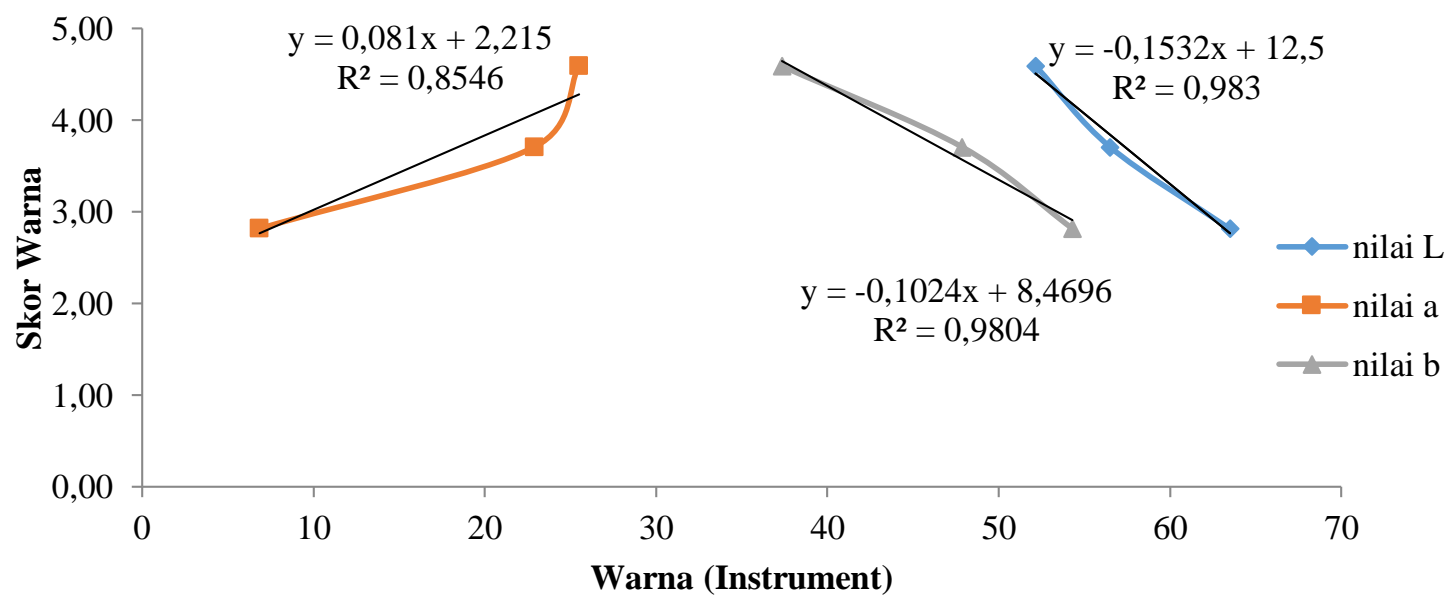

Gambar 5c. Hubungan nilai warna (instrumen) dengan skor kesukaan panelis terhadap warna manga

Warna merupakan faktor penting yang menjadi penentu bahan pangan akan dipilih atau tidak. Perbedaan warna pada ketiga jenis mangga dipengaruhi oleh faktor genetika. Gambar 5c menunjukkan bahwa panelis cenderung menyukai warna mangga dengan semakin rendahnya nilai lightness dan nilai $b$ mangga serta semakin tingginya nilai a. Nilai a menunjukkan tren garis lurus, sehingga dapat dijelaskan bahwa panelis menyukai warna mangga sampai dengan batas nilai a tertentu. Hubungan antara nilai lightness, nilai a dan $b$ terhadap skor kesukaan panelis terhadap warna dapat ditunjukkan dengan persamaan berikut:

Skor warna $=-0,153$ (lightness) $+12,5$ dengan $R^{2}=0,983$.

Skor warna $=0,081$ (nilai a) $+2,215$ dengan $R^{2}=0,854$.
Skor warna $=-0,102$ (nilai $b)+8,469$ dengan $\mathrm{R}^{2}=0,980$.

\section{KESIMPULAN}

Berdasarkan penelitian diatas maka dapat disimpulkan beberapa hal sebagai berikut:

1. Terdapat hubungan antara karakteristik fisik, kimia terhadap skor kesukaan panelis terhadap rasa dan warna

2. Penerimaan panelis meningkat dengan meningkatnya total gula pada mangga dan menurunnya $\mathrm{pH}$. Hubungan antara gula total dan skor rasa panelis ditunjukkan dengan persamaan berikut:

Skor Rasa $=0,715$ (gula total) 8,245 dengan $\mathrm{R}^{2}=$ $0.743 \ldots \ldots \ldots . . .(1)$ 
3. Hubungan antara nilai $\mathrm{pH}$ dan skor kesukaan panelis terhadap rasa mangga dapat ditunjukkan dengan persamaan berikut:

Skor rasa $=0,904(\mathrm{pH})-1.357$ dengan $R^{2}=0,893$

4. Panelis menyukai mangga dengan tingkat kecerahan rendah. Hubungan antara nilai lightness, nilai a dan $b$ terhadap skor kesukaan panelis terhadap warna ditunjukkan dengan persamaan berikut:

Skor warna $=-0,153$ (lightness) + 12,5 dengan $R^{2}=0,983$.

Skor warna $=0,081$ (nilai a) +

$2,215 \quad$ dengan $\quad R^{2}=$
$0,854 \ldots \ldots \ldots . . .(4)$

Skor warna $=-0,102$ (nilai $b$ ) + 8,469 dengan $\mathrm{R}^{2}=$ $0,980 \ldots \ldots \ldots . . .(5)$

\section{DAFTAR PUSTAKA}

Broto, W. 2003. Mangga, Budi Daya, Pascapanen dan Tataniaganya. Agromedia Pustaka, Jakarta.

Colaric, M., Veberic, R., Stampar, F dan Hudina, M. 2005. Evaluation of Peach and Nectarine fruit quality and correlations between sensory and vhemical attributes. J.Sci Food Agric 85: 2611-2616 (2005).
Hutching, J. B., 1999. Food Color and Appearance. Second Edition. Aspen Publishing, Inc., Maryland.

Kader, A. A. 2002. Quality and safety factors: Defnition and evaluation for fresh horticultural crops. Postharvest technology of horticultural crops : 279-285.

Lebrun, M., Plotto, A., Goodner, K., Ducamp, M. N., and Baldwin, E. (2008). Discriminationof mango fruit maturity by volatiles using electron nose and gas chromatography.Postharvest Biology and Technology.48:122131.

Satuhu, S. 2000. Penanganan Mangga Segar Untuk Ekspor. Penebar Swadaya, Jakarta.

Sivakumar, D., Jiang Y., and Yahia, E.M. 2010. Maintaining mango (Mangifera indica L.) fruit quality during the export chain. $A$ review. Food Research International.03411:1-10.

Soekarto, S. T., 1985. Penilaian Organoleptik. Penerbit Bhratara Karya Aksara, Jakarta.

Winarno, F. G., 1997. Kimia Pangan dan Gizi. PT. Gramedia, Jakarta. 